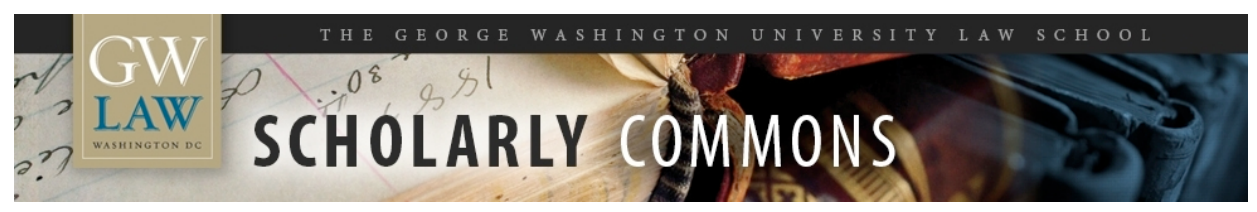

\title{
Playing with Fire: Feminist Legal Theorists and the Tools of Economics
}

Neil H. Buchanan

George Washington University Law School, neilhbuchanan@gmail.com

Follow this and additional works at: https://scholarship.law.gwu.edu/faculty_publications

Part of the Law Commons

\section{Recommended Citation}

Neil H. Buchanan, Playing with Fire: Feminist Legal Theorists and the Tools of Economics in FEMINISM CONFRONTS HOMO ECONOMICUS (Martha A. Fineman \& Terence Dougherty, eds., Cornell University Press, 2005).

This Book Part is brought to you for free and open access by the Faculty Scholarship at Scholarly Commons. It has been accepted for inclusion in GW Law Faculty Publications \& Other Works by an authorized administrator of Scholarly Commons. For more information, please contact spagel@law.gwu.edu. 


\title{
Playing with Fire: Feminist Legal Theorists and the Tools of Economics
}

\author{
by \\ Neil H. Buchanan \\ in
}

FEMINISM CONFRONTS Homo ECONOMICUS, Martha A. Fineman,

Terence Dougherty, eds., Cornell University Press, 2005 


\title{
FEMINISM CONFRONTS HOMO ECONOMICUS
}

Gender, Law, and Society

\author{
EDITED BY \\ Martha Albertson Fineman \\ and Terence Dougherty
}

CORNELL UNIVERSITY PRESS ITHACA AND LONDON 


\section{CONTENTS}

Part I: Law and Economics and Neoclassical Economic Theory

I

I. Economic Rhetoric, Economic Individualism, and the Law and Economics School Terence Dougherty

3

2. The Demoralization of Economics: Can We Recover from Bentham and Return to Smith? Deirdre McCloskey

3. Separative and Soluble Selves: Dichotomous Thinking in Economics Paula England

Part II: Feminism Confronts Neoclassical Economic Theory and Law and Economics

4. Playing with Fire: Feminist Legal Theorists and the Tools of Economics Neil H. Buchanan

5. Feminism and Eutrophic Methodologies Douglas A. Kysar

6. Private Property, the Private Subject, and Women: Can Women Truly Be Owners of Capital? Elizabeth Mayes

7. Nest Eggs and Stormy Weather: Law, Culture, and Black Women's Lack of Wealth Regina Austin

8. Deconstructing the State-Market Divide: The Rhetoric of Regulation from Workers' Compensation to the World Trade Organization Martha T. McCluskey

Part III: The Costs of the Free Market: Theories of Collective Responsibility and the Withering Away of Public Goods

9. Cracking the Foundational Myths: Independence, Autonomy, and Self-Sufficiency Martha Albertson Fineman 
Io. The Politics of Economics in Welfare Reform

Martha T. McCluskey

I I. Deterring “Irresponsible” Reproduction through Welfare

Reform Linda C. McClain

I2. Feminist Economics: Implications for Education

Myra H. Strober

Part IV: Feminism, Economics, and Labor

I3. The New Face of Employment Discrimination

Katherine V. W. Stone

I4. Contingent Labor: Ideology in Practice Risa L. Lieberwitz

I 5. Commodification and Women's Household Labor

Katharine B. Silbaugh

I6. Is There Agency in Dependency? Expanding the Feminist Justifications for Restructuring Wage Work Laura T. Kessler

Part V: Economics and Intimacy: Gendered Economic Roles and the Regulation of Intimate Relationships

I7. What Do Women Really Want? Economics, Justice, and the Market for Intimate Relationships June Carbone

I 8. Can Families Be Efficient? A Feminist Appraisal

19. Some Concerns about Applying Economics to Family Law Margaret F. Brinig

20. The Business of Intimacy: Bridging the Private-Private

Distinction Martha M. Ertman 


\title{
Playing with Fire
}

\author{
Feminist Legal Theorists and the Tools of Economics
}

Neil H. Buchanan

[Author's note: From 1995 through 1998, Prof. Martha Fineman led a group of feminist legal scholars and other interested social scientists through a series of workshops. These workshops were devoted in large part to a discussion of how feminist legal theorists should respond to the so-called Law and Economics movement (and its theoretical basis, neoclassical economic theory), which had become an important force in so many other areas of legal scholarship. This essay, first drafted in 1998 , is based on my presentation at one of those workshops. Although I have subsequently earned a law degree, I have chosen here to preserve the outsider's viewpoint of the original draft and thus not to alter the essay extensively based on my studies in law school and afterward. While I have added some updated references and cited several sources that are likely to be familiar to legal scholars, the arguments that follow are those of a "dissenting economist" who was engaged in his first scholarly interaction with feminist legal theorists.]

Legal theorists obviously cannot and should not ignore economics. ${ }^{1}$ Economic issues-which have long been recognized as central to certain areas of legal analysis, especially tax and antitrust law-are increasingly implicated in virtually every area of legal analysis, from labor law to contracts to property theory. The question for legal scholars is often not whether to discuss economic issues, but how.

During the discussions at Prof. Fineman's recent feminist legal theory workshops, several participants argued that feminists should use the "tools" of mainstream economics to build a more rigorous foundation for their analyses. Feminist legal theorists, it was argued, had their hearts in the right place, but their arguments lacked sufficient intellectual ("hard-headed") rigor to carry the day. Based on this view, the best strategy would be to use economic tools (which, these participants argued, are value neutral) to build a rigorous, logical foundation on which feminist legal theorists could confidently stand.

If the claim is simply that emotion alone cannot win a debate, or that feminists would be well served by availing themselves of logical constructs that they are supposedly ignoring, then there certainly is no argument. However, feminists are not guilty of the charges implicit in such an assertion. Feminist theorists in all fields have long used pointed and brilliant logic in building their arguments, employing all manner of formal analytical methods. To suggest otherwise is nothing less than an insult that legitimizes the most retrograde gender stereotyping. 
The problem-which applies to all areas of legal analysis, not just feminist legal theory-is that the use of so-called economic tools is almost certain to lead to the unintentional importation of hidden assumptions that permeate mainstream economics. Yet the lure is always there. Why not use a model that assumes rational choice by rational actors? Why not use the neoclassical toolbox to measure costs and benefits, to show that a particular policy is or is not viable? Why not use neoclassical models, change an assumption or two, and show that a different result can be derived? Why not, indeed?

This essay presents two reasons why not. First, the supposed intellectual rigor of neoclassical economic theory is-to a surprising degree-a mirage. ${ }^{2}$ These tools, far from being as powerful as their advocates suggest, are actually miscalibrated and easily misused. Therefore, mutating legal theory (indeed, mutating any theory) to conform to the methodological preferences of neoclassical economists is a mistake. Second, at least some of the hidden assumptions of neoclassical economics are fundamentally reactionary and incompatible with the goals of most feminist legal scholarship-indeed, with socially progressive scholarship in general. Using neoclassical economic analysis (even, or perhaps especially, when "turning it on its head") is the slipperiest of slopes, inviting even the careful analyst to commit lapses of reasoning and to reinforce moral and logical presumptions that should be exposed and opposed.

This slope is slippery in another way as well. Those fields that have started down the road of adopting "some" mainstrean economic methods have almost uniformly found that the previously established methodologies have come to be replaced by the neoclassical approach. Because it is not obvious, a priori, that mainstream economic methods leave so little room for alternative approaches, we must all learn from the hard experiences of others who once believed that economics could provide a neutral set of tools.

This is not to say that legal theorists should leave "economic subjects" off of their agenda. It should go without saying (but, based on the discussions in the workshops, it apparently does not) that feminist legal theorists shouldemphatically should! - analyze economic issues. In doing so, however, they must make sure that the methods they adopt to pursue such analyses do not reinforce the hidden prejudices of neoclassical economics. Thus, although the motivation for this essay was found in discussions among feminist legal theorists, the arguments are important to scholars in every field of social inquiry who might wish to integrate economic issues into their research. ${ }^{3}$

In this essay, I first describe what neoclassical economics is. I then attempt to explain why neoclassical economics is intellectually unsatisfactory, exposing what purports to be its greatest strength (logical coherence) as its principal weakness. I then proceed to explain why neoclassical economics should be morally troubling to feminist legal theorists (and others), emphasizing the prescriptive conclusions that the assumptions of neoclassical economics lead one 
to make. Finally, I conclude by suggesting that feminist legal theorists should be mindful of the experiences of other academic disciplines in which scholars have made the mistake of believing that they can put the genie back in the bottle.

\section{Defining Neoclassical Economics}

What is neoclassical economics? While an attempt at an exhaustive answer to that question appears below, it might be helpful to offer here a simple yet suggestive comment attuned to this essay's presumed audience of legal theorists: neoclassical economics is the theory behind the Lochner decision. ${ }^{4}$ Although much of what follows is of an abstract technical nature, therefore, the legally trained reader might profitably use Lochner as a touchstone for understanding what is ultimately at stake.

Contrary to what many economists are taught, the moral principles underlying an economic theory are what define a school of thought. Neoclassical economics is, at its core, a theory of value. That is, all analyses flow from an assumption about how we should determine the value of goods and services.

This assertion itself is foreign to neoclassical economists, who typically imagine that they are involved in a "value-neutral" enterprise. Almost every introductory economics course goes to great lengths to assure its teenaged students that there is a difference between "positive economics" and "normative economics." The former is the very essence of "science," in which only propositions of logic are entertained, while the latter involves moral judgments, about which economic scientists are appropriately mute. "We will discuss 'if-then' statements, not 'should' statements," the students are soothingly assured. "Just learn the science, and you can then use it for whatever moral purposes you like."

Despite these claims, normative language is nearly irresistible when using neoclassical analyses. Even in an essay such as this, it is tempting to describe the results of a standard neoclassical analysis with statements such as "Thus, a subsidy would make things worse, not better," rather than the more neutral, "A subsidy moves the market away from a particular type of efficiency." The progression from fully descriptive language with all assumptions noted (such as the definitional paragraphs later in this section), to largely descriptive language with the assumptions and peculiar definitions unspoken (for example, "Perfectly competitive markets are efficient"), to normatively laden shorthand ("Eliminating the subsidy would make things better") is obvious when one stops to think about it; but it is precisely because people so frequently do not stop to think about it that it happens.

The problem, however, is not simply rhetorical. Neoclassical economics does not merely sound normative some of the time. It is normative all the time. 
It starts, as noted earlier, with a definition of value. (How much more normative could one be than to make a judgment about what things are worth?) The criterion for measuring value, according to neoclassical theory, is the willingness-to-pay principle. This says simply that things are worth what buyers are willing to spend for them.

An especially vivid example should illuminate the concept. In 1998, Prof. Deirdre McCloskey gave a guest lecture to the economics department of a Ph.D.-granting university. She argued, among other things, that economists should become more interdisciplinary, using appropriate methods currently employed in the fields of medicine, engineering, and history. During the question-and-answer period, the first person to speak was the chairman of the host economics department. A committed neoclassical economist, he announced: "I do not want any of our graduate students to believe that they should leave the economics department and join the history department. You should be aware that new economics Ph.D.'s are paid twice what new history Ph.D.'s are paid. So that settles the question of value!" McCloskey, of course, had never suggested anything of the kind. Even so, the idea that economists might debase themselves by studying history so incensed the chair that he was refreshingly blunt about what really counts. (He could not, however, explain why his graduate students should not go to law school, where they could guarantee themselves markedly higher salaries than economics professors will ever earn.)

What are the alternatives to this criterion for measuring value? In economic literature, to the extent that this issue is discussed at all, the discussion is usually limited to a single alternative: the labor theory of value. If goods are not worth what people are willing to pay for them, perhaps they are worth the total labor effort expended in making them. The dividing line between classical and neoclassical analysis, in fact, is usually drawn at the point at which economists stopped arguing about theories of value. Neoclassicism emerged as the dominant force over one hundred years ago, when a critical mass of economists concluded that the willingness-to-pay principle had "won" the war of value theory. They then proceeded to build what we now call neoclassical economics on that base.

For the purposes of social and legal analysis, however, many alternative theories of value are available. All one needs is an answer to the question "What determines what something is worth?" One might answer, "Things are valuable according to their biological necessity for humans," or "Things are valued according to their contribution to justice," or "Things are as valuable as God says they are." People can and do easily hold any combination of these theories of value, even when they sometimes provide inconsistent answers to the question.

Therefore, although most economists believe that there are only two available choices (willingness to pay or the labor theory of value), legal theorists are clearly familiar with the notion that value can be measured in different 
ways. This is good, and legal theorists should not willingly limit themselves to the peculiar way that neoclassical economics defines a concept as fundamental as value.

\section{Pareto Efficiency and Deadweight Loss}

The familiar demand and supply curves from introductory neoclassical economics courses are nothing more than a graphical representation of the willingness-to-pay principle (and hence the neoclassical theory of value). Demand curves are defined as the set of prices that people would be willing to pay for various quantities of a single good, given the values of relevant variables such as income, tastes, and so forth. Supply curves are correspondingly defined as the set of prices that firms would be willing to accept in order to provide various quantities of the good, given the firms' technologies, cost of inputs, and so forth. (Strictly speaking, then, this should be called a "willingness-to-bepaid principle.")

The next step in neoclassical analysis, after that of defining how the values of all items should be determined, is to determine the optimal quantities in which items should be produced. (Note again the use-by supposedly neutral scientists-of such values-laden terminology.) This is done by drawing the inference that a unit of a good should be produced if the demander values it more than the seller does, whereas a good should not be produced if the producer would require a higher price to produce it than a demander would be willing to pay.

The seductive logic of free markets, of course, is based on the idea that selfinterested individuals will never trade goods for which such a mutually beneficial bargain does not exist-and will always trade goods for which such a bargain does exist. After all, why would any noncoerced parties engage in a trade in which the supplier requires a price that is higher than the demander is willing to offer? Similarly, why would they not trade when the consumer is willing to pay more than the seller requires? The only thing left to do in the latter situation is to pick a price, which is what the Invisible Hand of the free market supposedly does for them.

This is where the concept of market equilibrium, or "market clearing," takes center stage. A market is said to be in equilibrium if the total number of units offered for sale at the going price is equal to the total number of units that buyers wish to purchase. This simply aggregates the intuition discussed above, saying that an entire market is in equilibrium if every trade that occurred in the market benefited both sides and if every such trade that is possible has actually been consummated. Again, this relies on the idea that the only reason that any goods would not be sold is that the seller is requiring a price that is higher than a noncoerced buyer would pay. The analogy to the physical notion of equilibrium is simply that there is nothing that would change the 
price and quantity in such a market except a disturbance from outside the system-a change in the determinants of supply and demand.

\section{General Equilibrium}

Under sufficiently stringent assumptions, there is a unique market-clearing output for every item at every point in time. Conceptually, it would be possible to compile a list of every good and service in the economy and then to figure out the market-clearing output in each market-assuming that all other markets have also produced their market-clearing outputs. Proceeding in such a manner, we might conclude that the market for Granny Smith apples would clear with 48,000 bushels being produced at the same time that the market for no. 2 pencils would clear with 2.745 million being produced, and so on for every good and service.

This set of outputs is achieved under the condition of "general equilibrium," which is defined as the point at which prices have been set simultaneously in every market such that all markets will clear. The concept is both powerful and subtle. At any point in time, a general equilibrium exists if the price for each good in the economy (both inputs, such as computer programming, and outputs, such as Twinkies) is such that every market is simultaneously in equilibrium.

When all markets have cleared in this way, the result is said to exhibit Pareto efficiency-but in a nonsynonymous switch, some economists revealingly insist on referring to this as Pareto optimality. ${ }^{5}$ In other words, systemwide market clearing and Pareto efficiency go together: when all acceptable trades have been made, the market has achieved the neoclassical economist's ideal of efficiency.

General equilibrium recognizes that markets are interrelated, for example, that changes in the market for gasoline affect supply and demand in the market for cars (as well as the markets for natural gas, lawnmowers, subway tokens, and so on). Therefore, if there is a change in the demand for gasoline (due to, for example, news of a previously unknown environmental harm caused by oil refining), the change in the price of gasoline will affect the markets for related goods. The changes in those markets will then affect still more markets, until the ripple effect has potentially affected every market in the economy.

Many readers might recall the equilibrium price as the one that is easily seen where the supply and demand curves intersect on the standard diagram in Economics IOI. Surprisingly, however, the price depicted on that ubiquitous graph is not necessarily -indeed, is almost certainly not-the general equilibrium price. Rather, it is the partial equilibrium price, which is merely the price that would clear a particular market, given the existing conditions (equilibrium or not) in all other markets. It does not require that all markets have cleared 
simultaneously. For example, if the market for gasoline is out of equilibrium in such a way that demanders are buying fewer gallons of gasoline than they might otherwise buy, they are likely to take the money that they would have spent on gasoline and spend it on something else (raising their demand for, say, video rentals). Similarly, because all prices will be different under this situation than under general equilibrium conditions, demanders (and suppliers) will be responding to a completely different set of prices, which will cause them to buy and sell different quantities than those that would be bought and sold in a Pareto-efficient system.

The brilliance of general equilibrium theory is its recognition that there might not be a way to set prices such that all markets are in equilibrium simultaneously. As discussed later in the chapter, the general conclusion reached by general equilibrium theorists is that one must make some rather strong assumptions in order to believe that a general equilibrium can even exist. Even then, moreover, that equilibrium can only be relevant for a given starting point of endowments of wealth, talent, social position, and so forth.

When a market or set of markets is not currently operating at its general equilibrium quantities, there are "deadweight losses." Deadweight loss is simply the dollar value of the difference between what a consumer would have been willing to pay and the amount that producers would have insisted upon receiving in order to produce the good, summed up for all units of underproduction or overproduction. ${ }^{6}$ For example, if production of DVD players is exactly one unit less than the Pareto-efficient output, and person A would have been willing to pay as much as $\$ \mathrm{I}, 000$ for that player while producer $\mathrm{X}$ would have sold it for as little as $\$ 200$, deadweight loss equals \$800. On supplydemand diagrams, deadweight losses are usually shown as triangular areas; so deadweight loss measurements are often casually described as deadweight loss triangles.

The $\$ 800$ deadweight loss is independent of the price that would have been charged, because a price of $\$ \mathrm{I}, 000$ would have implied $\$ 800$ of surplus (a.k.a. profit) to the producer and none to the consumer, whereas a price of $\$ 200$ would have implied a surplus of $\$ 800$ to the consumer and none to the producer, with any price in between implying surpluses that add up to $\$ 800$. However, to say that the economy has "lost" $\$ 800$ is a bit misleading because this is not necessarily money that anyone ever would have seen. If all of the surplus would have gone to the consumer, for example, the surplus simply tells us how much of a "deal" she feels she received; it does not describe anything tangible in her bank account. Therefore, the dollar values of deadweight loss calculations are often hypothetical.

For all the technical detail, deadweight loss is actually a simple idea. It merely claims to measure the aggregate value of any mutually acceptable transactions that outside forces have prevented from occurring. In the standard analysis, these outside forces are typically taxes, subsidies, and outright 
prohibitions and are called distortions (another favorite-and revealingword of neoclassicists).

The term typically applied to the analysis of deadweight losses is welfare economics, a misleading term but one that is (again) extremely revealing of the normative presumptions present in this supposedly positive analysis. The unacknowledged claim is that the general welfare of a society can be accurately measured by calculating the gains and losses that add up to deadweight losses. As a leading textbook in Law and Economics puts it: "General equilibrium is such a desirable outcome that it would be helpful to know the conditions under which it would hold." 7 "Welfare gains" to society are nothing more than reductions in deadweight losses.

\section{Applied Work versus Cutting-Edge Theory}

A further clarification is in order. Economic theorists who are currently developing the newest twists on market-based theories would largely consider the description above to be outdated and even pedestrian. As discussed later in the chapter, the current hot theoretical topics are largely in game theory and related areas. However, because this essay is dedicated to discussing how economic theory is being applied, by nontheorists and especially by noneconomists, it is important to describe not the cutting edge of new theory but the methods that are being used by the disciples and the recent converts.

In virtually every applied field (within economics and other social sciences, and in virtually every area of legal analysis), general equilibrium is still the accepted approach. Even macroeconomics has become, for the mainstream of the profession, applied general equilibrium theory. Papers with titles such as "General Equilibrium, Markets, Macroeconomics, and Money in a Laboratory Experimental Environment" and "Congestion, Land Use, and Job Dispersion: A General Equilibrium Model" are being churned out daily. ${ }^{8}$

This continued reliance on general equilibrium analysis is sometimes defended as being merely a necessary simplification of reality. For example, Elmendorf and Mankiw argue: "Mathematicians study Euclidean geometry (even though we now know that we live in a non-Euclidean world); physicists study frictionless planes (even though all real planes exhibit some friction); and economists study ... general-equilibrium models with complete and perfectly competitive markets (even though markets in actual economies are neither complete nor perfectly competitive)." 9

Note that Mankiw and Elmendorf do not say that general equilibrium is contingent on the distribution of endowments and the simultaneous clearing of markets. They simply state that the model is an ideal against which we can compare messy reality. It is not the laws of mechanics that are in question but merely the amount of friction in the plane. Clearly that analogy only makes sense if one assumes that the economy would act the way the neoclassical 
model says it would if only there were no imperfections. This is why the theory is called "general." Any apparent exception can be called a special case of the theory. Except in that tautological sense (that any behavior can be explained by constructing, post facto, a set of preferences that might have led to that behavior), there is no reason to believe that the neoclassical approach represents the true underlying model of economic behavior. Given its fundamental flaws (which I attempt to demonstrate below), the general equilibrium model should not be elevated in this way, as the perfect starting point from which all "exceptions" are modeled.

For most areas to which neoclassical economics has been applied, the agenda might simply be described as follows: find the deadweight loss triangle and eliminate it. Everything from discrimination to Social Security reform is fair game for the Pareto efficiency test. ${ }^{10}$ The Law and Economics movement appears to be based in large part on the assertion that legal analysis should be dedicated to designing a legal framework that guarantees that Pareto-efficient outcomes will be achieved in every market. This either involves removing legal structures that inhibit market clearing or, in the case of the so-called Coase theorem (see below), building legal structures (property rights) so that markets can achieve Pareto-efficient general equilibrium.

Therefore, it is important to understand what is hiding behind deadweight losses, both logically and morally. The next section is devoted to describingthrough an entirely "positive" analysis-just how weak are the intellectual underpinnings of neoclassical theory.

\section{Mainstream Economics Is Not Logically Rigorous}

Before proceeding, let me clarify the terms neoclassical economics and mainstream economics. The labels are somewhat arbitrary and are used loosely in the literature. For example, most economists who spend their time working on game theory still usually call themselves neoclassical economists because their work is typically merely an extension of neoclassical theory in different form. Moreover, they do not reject neoclassical doctrine-especially Pareto efficiency-but simply have chosen to analyze some issues through a different lens. The analysis in the rest of this essay, therefore, goes beyond a critique of strict neoclassical theory as defined above, extending to a more general analysis of the approaches embraced by most modern economists-even those who do not explicitly use general equilibrium theory in all of their studies.

The title of this section is probably the more surprising of the two central claims in this essay. Although many-but certainly not all-feminists are accustomed to thinking that there is something fundamentally troubling about the morality behind neoclassical economics, a surprisingly common belief appears to be that feminist legal theorists need to embrace some form of 
mainstream economics simply because it is so intellectually formidable. One can almost hear people saying to themselves, "Sure, I don't like the conclusions that the practitioners of neoclassical economics reach; but I have to force myself to think with my head and not with my heart. What they say is unfortunate, but it's just so darned logical." (This was certainly the tone of several presentations at Prof. Fineman's workshops.)

Neoclassical economics undoubtedly has the veneer of science. A Nobel Prize was created for economic "science" but not for any of the other academic social disciplines (although there has long been a Nobel Prize for literature). ${ }^{11}$ Acceptance into virtually all Ph.D. programs in economics is now more a function of an applicant's training in math than economics (to the detriment of undergraduates' learning experiences everywhere). Although some textbooks admit that economics is not a pure science, the desire to achieve greater stature by calling economics a science is manifest. ${ }^{12}$

Nevertheless, the logical underpinnings of mainstream economic methods are inadequate to justify the regard in which its practitioners would like to be held. Literally scores of articles and books have been written on every aspect of these shortcomings. Moreover, even those parts of what currently constitutes mainstream economics that are not explicitly wedded to neoclassical theory-in particular, game theory-are nowhere near as logically and mathematically consistent as many people seem to think. What follows is but a brief summary of some of the most serious (and often overlooked) problems with the logical constructs of mainstream economics, starting with general equilibrium theory and moving on to theoretical and empirical methods currently in vogue.

\section{False Trading}

Much has been made (and rightly so) of the highly questionable assumptions that must be accepted to justify standard economic models. I turn to those later in the essay. More fundamental than any of those assumptions, however, is the assumption that there is no "false trading." This is an assumption necessary to make even the most simple supply-and-demand analysis valid. If one removes this assumption alone, the logical structure of neoclassical theory is seriously undermined (if not irretrievably compromised).

False trading is any transaction that occurs when one or more prices are not at their general equilibrium values. ${ }^{13}$ For example, if there is a change in the economy (such as a change in tastes) that raises the general equilibrium price in a market from $\$ 8$ to $\$ \mathrm{IO}$, it is highly likely that some transactions will be consummated out of equilibrium, at prices of $\$ 8, \$ 9$, or even $\$$ I $_{5}$, before the new equilibrium can be reached. (This process of finding the equilibrium price is called tâtonnement, which is the French word for "groping.") Because people do not know what the equilibrium price is, they simply transact at the 
prices that exist at a given moment. Frequently, people later regret their purchases or sales (when the price later falls or rises, respectively), but that is the nature of market transactions in the real world.

Recognizing that time actually passes while prices change might not appear to be a serious challenge to the efficiency of markets. After all, if the process of groping eventually leads to the clearing of a market, what is the problem? In fact, however, because of false trading-even allowing all of the other standard neoclassical assumptions to hold-the Pareto-efficient result occurs only with vanishingly small probability. The noted economic theorist Franklin Fisher summarizes the situation: "We have no rigorous basis for believing that equilibria can be achieved or maintained if disturbed. Unless one robs words of their meaning and defines every state of the world as an 'equilibrium' in the sense that agents do what they do instead of doing something else, there is no disguising the fact that this is a major lacuna in economic analysis." 14

The likelihood of reaching general equilibrium is so remote, in fact, that neoclassical theorists often resort to invoking the so-called Walrasian auctioneer to justify using general equilibrium theory. This deus ex machina (named after Léon Walras, a neoclassical pioneer who did not actually invent the fictional character that bears his name) is simply assumed to set prices perfectly, as though through a huge auction, such that all markets clear instantaneously.

Nor are these problems somehow trivial or unimportant in their implications for neoclassical economic theory. Fisher goes on: "Tâtonnement stability requires extremely strong special assumptions. This has extremely important implications. Indeed it is not too strong to say that the entire theory of value is at stake." 15

In one sense, therefore, this result is "well known." That is, there is a literature that has shown that the conclusions typically drawn from supplyand-demand analysis (in particular, that "perfect" markets will reach Pareto-efficient outcomes) lack sound logical underpinnings. However, that is not the same thing as being "well known by most economists." Most graduate students in economics, to say nothing of undergraduates, are never taught such inelegant and inconvenient results. (Those who are, it seems, are often taught to then ignore those results.) The Law and Economics area is particularly problematic, because so many of those experimenting in this area have not undergone graduate training in economics, further increasing the likelihood that they have not come across the issues highlighted here.

\section{General Equilibrium}

As noted earlier in the chapter, mainstream economists typically consider general equilibrium to be the ideal to which markets should be allowed (or forced) to move. Indeed, Law and Economics is often explicitly concerned with setting up the legal system such that markets can achieve general equilibrium results. 
Beyond the problems of false trading just noted, though, given current policies in the United States and other mixed capitalist countries, general equilibrium is not achievable. Even if one looks solely at the usual suspects-minimum wage laws, unions, environmental regulations, or any other "distortions" that one might wish to name-the conclusion must be that the economy does not and cannot move to general equilibrium unless all such distortions are discontinued.

Therefore, even if one conceded (the completely incorrect argument) that the economy would achieve general equilibrium if only the government would completely butt out, that simply does not mean that we can actually achieve Pareto efficiency now if we proceed on a case-by-case basis. No individual market's output is likely ever to coincide with the output that that market would produce if the whole economy were in general equilibrium.

As emphasized earlier, it is of course true that a single market could clear (that is, all of the output currently produced by sellers could actually be purchased by buyers) when other markets do not. This post-tâtonnement partial equilibrium is what we are almost certainly observing when we actually come across a market without surpluses or shortages. In other situations, it is unlikely that the market is clearing at all, in either a partial or a general sense, because we so often see shortages and surpluses.

To illustrate again, we might estimate that the market for a particular type of computer would be in partial equilibrium when one million units per year are sold. If, however, all markets were in general equilibrium, the equilibrium output of laptops might be two million, or one thousand, or any other number completely unrelated to one million. Because Pareto efficiency is defined by those general equilibrium quantities, not partial equilibrium quantities, attempts to allow (or force) the laptop market to sell one million units are not merely completely arbitrary but actually inappropriate by their own standards.

Indeed, we could not even be sure that any particular change from a partial disequilibrium to a partial equilibrium would be a movement in the right $d i$ rection, much less to the Pareto-efficient output. To continue the example above, it is entirely possible for the general equilibrium output of computers to be 2 million, for the partial equilibrium output to be I million, and for the current (disequilibrium) output to be I. 5 million. Enacting policies designed to move the market to its partial equilibrium output would be inefficient, by Pareto standards.

One might argue that at least a partial equilibrium is something, that it anchors the idea that the legal system should allow and encourage people to make mutually beneficial transactions. The point of general equilibrium, though, is that a transaction that is mutually beneficial in one situation might not be-indeed, is unlikely to be-in another. If the markets for hot dogs and steak are both in partial equilibrium but the market for low-wage workers is not (because of some market imperfection that results in unemployment), then the outputs in all three markets are unlikely to be Pareto-efficient. That is, if a 
person is willing to buy three pounds of hot dogs per month and no steak, both quantities are likely to change if the person is suddenly able to find a job because the labor market clears. Even the primacy of mutually agreeable transactions is, therefore, undermined by the reality that the market system is almost certainly never in general equilibrium. ${ }^{16}$

POLICY ANALYSIS AND EFFICIENT BREACH

A central claim of mainstream economics is that it is exceptionally well suited to assist us in comparing policy choices. Indeed, its more aggressive adherents would claim that only neoclassical economics is able to provide such guidance. ${ }^{17}$ Even in a more modest form, however, the point seems to be that economic analysis allows us to make important comparisons: "Legal rule A is more efficient than legal rule B." "Policy X results in less deadweight loss than policy Y." The underlying definition of efficiency is, however, dependent on too many contingencies to be meaningful. This problem is, moreover, not empirically testable. It is a matter of fundamental unknowability. If every Pareto-efficient output can only be meaningfully measured if we know what general equilibrium would look like, then we should not use misleading proxies for Pareto efficiency as criteria to differentiate among actual policy choices.

Even at the least aggregated level - the individual cause of action in lawthis problem erodes the credibility of neoclassical analysis. In contract theory, so-called efficient breach describes the conditions in which a party should be allowed (and perhaps even encouraged) to breach a contract. The reasoning is merely a single-case version of Pareto efficiency: let party A breach if her gains from breaching are greater than party B's losses, with A compensating B by paying B's expectation damages. Whatever one might think about that prescription as a policy matter, it cannot be justified by true Pareto efficiency because there is no consideration of whether A's gains and B's losses will change when other variables change. Furthermore, if we encourage A to breach today, based on variables that have changed since yesterday (and might well change tomorrow), then we have no basis to call this "efficient" unless one simply conflates efficiency with expediency.

ENDOWMENTS AND GENERAL EQUILIBRIUM

A final point remains, perhaps the most important of all. Even if one were willing to stipulate that general equilibrium could be achieved, one must remember that Pareto efficiency is based on the shapes and positions of all of the demand and supply curves, which in turn are based on the endowments of wealth, property, talents, and so forth, possessed by members of the economy when trading begins. 
Therefore, there must be a different Pareto-efficient general equilibrium for every set of endowments. That is, if we could bring the Walrasian auctioneer to life and learn the quantities that would prevail if the economy were to reach general equilibrium, those quantities would all change if people possessed different amounts of wealth, skills, and so on. Indeed, there is potentially a unique general equilibrium for each and every possible set of endowments. To say that a quantity of output is Pareto-efficient thus requires one to specify which set of endowments one is using to generate supplies and demands.

The particular set of endowments with which most neoclassicists concern themselves is, perhaps not surprisingly, the one corresponding to the status quo. If the current set of endowments defines the general equilibrium outputs against which deadweight losses are measured, then any attempt to change people's endowments is, by definition, inefficient. If an economy has a highly unequal distribution of endowments, therefore, redistributive policies will always make someone worse off (even after compensation) than they would be in the general equilibrium that is based on those endowments.

Pareto efficiency as a general concept thus need not preclude the redistribution of endowments; when coupled with the assumption that the current distribution of endowments defines efficiency, however, it must obviously preclude any such redistribution-and it does so tautologically. The moral implications of this are discussed in detail later in the chapter. In addition, if Pareto efficiency is not moored to some set of endowments, the entire notion loses its meaning and usefulness. Every policy change is both efficient and inefficient, depending on the starting point.

To summarize, neoclassical economic theory rests on three pillars: willingness to pay as a standard of value, general equilibrium as the (desired?) outcome of market interactions, and an arbitrary specification of the endowments (usually the current endowments) that determine individuals' market supplies and demands. Each of these is, at best, highly contentious. More importantly, and more dangerously, they distort our views of both the real and the possible.

\section{Those Assumptions}

Suppose that there were no false trades and that one could meaningfully define and achieve general equilibrium. There are still profound reasons why neoclassical welfare results are highly unlikely to occur. The standard assumptions taught in a comprehensive undergraduate introduction to microeconomics are (I) there are no monopolistic buyers or sellers; (2) there is free entry and exit from markets; (3) goods are homogeneous; (4) there are no effects of economic choices which are external to the decision maker ("no externalities"); and (5) perfect information exists in all markets. Although all of these assumptions are unrealistic, and all have been found to compromise the claim that economic markets are Pareto-efficient, only the fifth assumption is emphasized below. 
This is not because the others are uninteresting but simply that there are even more profound gaps in the neoclassical argument that arise from other, hidden assumptions.

Beyond these five assumptions, a number of more fundamental and subtle issues are too often unexplored. Some are entirely technical, such as the assumption of gross substitutability of goods (that is, that no good is totally unique in its ability to satisfy preferences), yet are still highly questionable. Others are more practically and philosophically interesting.

The building blocks of supply and demand curves are technology and preferences. Supply and demand curves are constructed on the assumption that the technology of production (defined broadly to include the organization and methods of the production process) and people's preferences (for work versus leisure, for present versus future consumption, as well as for all types of goods) are fixed. Neoclassicists refer to technology and preferences as "deep parameters." 18

If either technology or preferences change, however, the curves shift, and there is a new general equilibrium. ${ }^{19}$ Of course neoclassicists spend a great deal of time discussing the results of these shifts, using both static and dynamic modeling strategies. However, this implies that the entire structure on which a particular general equilibrium result is built can be changed by nothing more substantial than whims and moods.

Therefore, the general equilibrium that defines a Pareto-efficient outcome can change while the economy is adjusting toward it. One way to avoid this inconvenient fact is to invoke the assumption of no false trading, discussed above, with each moment in time defined by its own general equilibrium prices and quantities. This is known as intertemporal equilibrium. ${ }^{20}$

Even if false trading is assumed away, however, the problem is not obviated, because the design of policies to replicate Pareto-efficient outcomes can only be based on old information about the economy (and, indirectly, about the underlying preferences and technology). For example, if one has concluded that there is an inefficient amount of saving in the economy, the standard proposition is to enact yet another law to encourage people to save. During that process, however, there is nothing preventing the underlying preferences for current versus future consumption to change such that the economy could suddenly be oversaving. The subsidy to saving would make the world less Paretoefficient, not more so.

In addition to these practical considerations of the timing and structure of policies, there is the question of the nature of preferences themselves. The standard neoclassical analysis requires the exclusion of "subjective value preferences by members of a society," 21 which in practical terms means that people mind their own business. If a reallocation of goods between two people makes both better off, this is supposed to be the end of the story. There has been a Pareto-efficient increase in trade, and the world is happier for it. 
If, however, a third person has a preference for, say, the original allocation of goods between the two traders (for example, a parent who does not want his fruit-loving daughter to trade with his vegetable-loving son, lest their diets become unbalanced), then the trade does not move the world toward Pareto efficiency. In fact, a limitless number of such inconvenient types of preferences make the standard results impossible. Although neoclassicists generally refer to such preferences as unusual, this remains unproven, to say the least.

\section{Information Economics}

Of the five assumptions that underlie the claim that free markets will always result in Pareto-efficient outcomes, I now turn to the fifth assumption-that there is perfect information in economic markets.

The perfect information assumption means that all buyers and sellers have full knowledge of each other's existence, of the prices for which all goods can be traded, and of the qualities of the products that are for sale. For example, in neoclassical theory as applied to labor markets, one must assume that workers (that is, suppliers of labor) as well as firms (demanders of labor) know with equal certainty just how hard the workers will work if they are hired. Similarly, in the used car market, buyers of used cars must be assumed to know exactly as much about the quality of the car as the seller does.

One important body of work, known as information economics, analyzes from a variety of perspectives the implications of abandoning the assumption of perfect information. One of the breakthrough essays was, indeed, an analysis of the used car market by Akerlof. ${ }^{22}$ The market for "lemons," that is, used cars, is hampered by an insurmountable information problem. Sellers of used cars know much more about their cars' quality than do potential buyers, but sellers of high-quality used cars cannot credibly convey this information to buyers because both sides recognize that self-interest may induce a seller to lie about her car's attributes. Akerlof showed, using accepted mathematical techniques, that if one takes into account this asymmetry of information, then this market cannot reach the Pareto-efficient equilibrium-or even a partial equilibrium. Buyers will hedge against the likelihood of buying a lemon by offering artificially low prices for all cars. Rational sellers of all but the lowest quality cars will be led to choose not to sell their cars at all, because the low price offered would make it better to continue to drive the cars rather than sell them.

Because the problem of informational asymmetries is endemic to all economic markets, the insights gained from Akerlof's work were readily extended to other goods. Lenders cannot possibly know with certainty whether a borrower intends to repay the loan or to default; insurers cannot know with complete accuracy if applicants for life insurance policies are already dying or if they intend to depart sooner than expected; lawyers do not know if their 
potential clients are likely to sue for malpractice (nor does the client know if the lawyer is likely to commit malpractice); employees do not know if bosses are really going to give them the raises and promotions that they promised, and so forth.

Obviously, the possibilities are endless, and the resulting literature has been large and impressive. Summarizing the broad conclusions of the field that he largely helped to create, Stiglitz concluded that "the field of information economics has established that: (I) in general, markets are not ... Pareto efficient; (2) markets may not clear." 23 The implication is clear: altering even one assumption of the standard neoclassical model opens up a universe of nonPareto-efficient equilibria.

On one level, of course, even the most devoted neoclassical economist will admit that information is imperfect. The only question is whether the imperfections are large or pervasive enough to matter. In that sense, therefore, information economics can be seen as a generalization of neoclassical economics-with the usual neoclassical conclusions constituting the baseline from which deviations due to information problems are measured. Indeed, information economics still accepts the conclusion that markets will reach Paretoefficient outcomes in the rare (or, more likely, impossible) case where there is perfect information.

Moreover, information economics does not challenge the idea that Paretoefficient outcomes would be desirable if they could be achieved. The theory of value is still the willingness-to-pay principle, and welfare outcomes are expressed in terms of deadweight loss. The innovation of information economics is its recognition of additional barriers to markets reaching Pareto-efficient equilibria, but it does not pose a challenge to the foundation underlying the Pareto efficiency concept.

\section{EFFICIENCY WAGES}

The debate over the theory of efficiency wages is illustrative. This theory recognizes that bosses do not go into the labor market because they want to hire an hour of a worker's time. Instead, they wish to purchase actual productive effort. Because bosses obviously cannot read potential employees' minds, however, workers know more about how hard they intend to work (as well as how capable they are of doing the kind of work for which they are being hired) than their bosses do. If workers must be paid by the hour (rather than at piece rates), this creates an inherent conflict in the workplace.

Efficiency wage theory predicts that bosses will offer an artificially high wage (artificial in the sense that it is not the market-clearing wage) in the hope that this will allow them to hire the most diligent workers. ${ }^{24}$ Although the bosses realize that the resulting applicant pool will necessarily include a mixture of both good and bad workers, their fundamental lack of information 
leaves no alternative. Offering a high wage at least increases the number of high-quality applicants in the pool, which increases the odds of hiring some good workers.

This high wage, however, creates involuntary unemployment precisely because it is designed to provide bosses a larger pool of workers than they would have found in equilibrium. Crucially, therefore, the wage does not decline in the face of a surplus, and the involuntary unemployment does not disappear. This is impossible in the neoclassical view of labor markets, where rational maximizers methodically and relentlessly bring disequilibrium prices and wages into line.

The neoclassical response? Rational workers and employers will realize that the problem arises from the lack of a mechanism to guarantee predictable levels of effort and productivity. Therefore, profit-maximizing firms will "bond" workers, that is, they will require that workers post as collateral an efficient sum of money against their possible laziness. ${ }^{25}$ If a worker is less productive than she promises to be, the boss will receive the bond. This process allows firms to hire workers for the equilibrium wage, because they do not have to pay a premium to find the best workers. Instead, the best workers reveal themselves by being willing to post bonds.

This, of course, leads to further replies by information economists about the feasibility of bonding. ${ }^{26}$ For example, many (most?) workers do not have money on hand that they can tie up in a bond. Even if they did, they could be forgiven if they imagined that bosses would have an incentive to make false claims of employee shirking in order to confiscate the bonds. The practical problems with any bonding scheme are too numerous to list here. The theoretical point is that bonding simply replaces one type of information problem (Which workers will shirk?) with others (Which bosses will lie? Which bonding companies will embezzle funds?).

Even so, these practical arguments merely bring forth further claims that markets will come into existence to make bonding feasible (for example, bonding the bonding companies). Any practical or theoretical attack on the neoclassical orthodoxy can always be met with the claim that rational maximizers will make the problem go away.

WHAT IS THE “MONEY” ON THE TABLE?

The discussion of efficiency wages highlights another revealing synonym for deadweight loss: "money left on the table." This phrase invokes a precisely incorrect image, that markets are so efficient that no rational actor would pass up the opportunity to grab money that is there for the taking. Every profitable trade will be made. In response to a claim that, for example, "workers obviously do not take out performance bonds," the response is, "Why wouldn't they? Not to do so leaves money on the table." If there is 
money left on the table, therefore, it must be because of some inappropriate intervention.

This example highlights just how illusory the concept of loss really is here. If there is a deadweight loss, that merely means that there are people who might have made trades with other people, but they did not. That is not a loss in the immediate sense of a decrease in one's bank balance but rather a hypothetical loss against an imaginary baseline. If, because of false trading or other so-called imperfections, people are unaware of the existence of unsatisfied trades, nothing automatically forces the trades to occur.

\section{Deconstructing Property Rights}

A prominent area in which mainstream economics purports to provide logical rigor to the law is in the analysis of property rights. Although property is a central concern for both legal theory and economics, mainstream economists favor a highly misleading approach to property theory that is based on an artificial distinction between "market" and "nonmarket" actions-between what is internal to a market and what is external. The result is a built-in bias against anything that can be described as nonmarket action (which is usually, of course, governmental action).

One of the assumptions of perfectly competitive markets, noted above, is that there are no externalities. Externalities are defined as any effects of an economic decision that are not directly experienced by the economic agent making the decision. The classic example is, of course, pollution. It is elementary to demonstrate, on a standard supply-and-demand graph, that the presence of an externality will cause even a market without false trading and with a Walrasian auctioneer to deviate from Pareto efficiency. This type of market failure is widely viewed as a situation that calls for nonmarket intervention by governments.

In perhaps the most well-known convergence of neoclassical economic theory and legal analysis, however, advocates of the so-called Coase theorem claim that the real problem with externalities is that property rights have not been properly articulated, assigned, and enforced. Supposedly all one needs to do is give someone (anyone!) the ownership rights to an external good, and the new owners will internalize the externality automatically and efficiently. "Missing markets" are the problem, so the solution is to allow the necessary markets to come into existence. (And they will come into existence, because otherwise there will be money on the table.) The government does have a role, but only in the maintenance of a system of property and contract law.

The potency of this theorem cannot be underestimated. Indeed, when listing the five assumptions of perfect competition, some economists go so far as to replace the statement "No externalities" with "Property rights are well defined." The policy implication is obvious: no market interventions of any 
kind are justifiable. Pollution should not be combated with effluent fees (taxes on pollution) or direct regulation, but rather by giving someone ownership of the item being polluted.

The surprising corollary of this theorem is that it does not matter to whom a property right is assigned. If a polluter is given ownership of the river that it is polluting, people who care about the river can "buy off" the company to reduce or eliminate its pollution. If, on the other hand, another group is given the property right, the polluter can pay them for the right to pollute.

This symmetry is not merely incidental but simply must be true for the theory to work. Because there is only one Pareto-efficient general equilibrium set of outputs, the market must move to that single equilibrium-no matter who owns the property.

It is beyond the scope of the current investigation to critique the Coase theorem and all of its applications to economics, law, and other social inquiry. The point here is limited to this final corollary of the Coase analysis. For all of its supposed potency, the Coase theorem rests on a very special assumption about preferences, even if one accepts the rest of the assumptions necessary to drive the analysis. One must assume that there are no income effects resulting from the granting of the rights. ${ }^{27}$ This means that if a person notices that she now possesses new property and is thus wealthier, she nevertheless will not change her relative desire for one good more than others. That is, knowing that you now own a lake and all of the land around it, you increase your demands of all goods in equal proportion rather than buying relatively more Rolls Royce limousines than you used to buy.

Clearly this is unlikely in the extreme, and awarding property rights to more than one person only complicates matters. Thus, even if it actually were possible to figure out which property rights are undefined, to define them, and to award them, the market is highly unlikely to generate Pareto-efficient results.

One possible response to this difficulty would be to return to the approach mentioned earlier, that is, that the best way to deal with market failure is to intervene in the market directly, through taxes or subsidies calibrated to achieve Pareto-efficient outcomes. However, this approach would again elevate the Pareto criterion above all others as the sole arbiter of right and wrong. This is neither good science nor good policy.

\section{THE RHETORIC OF MARKETS}

The Coase analysis provides an ideal vantage point from which to describe a fundamental philosophical critique of the neoclassical approach. McCluskey brings together a feminist critique of market ideology and the tools of literary deconstruction to expose the central rhetorical maneuver that is typically accepted by both defenders and attackers of the neoclassical approach: the 
definition of "action within the market" versus "action that interferes with the market." 28

As McCluskey demonstrates, and as is implicit in the Coase analysis, the market is inherently defined by the government. Even so, arguments in favor of having the government define and protect certain rights (such as workplace safety rules) are attacked for creating deadweight losses. These rules could easily be cloaked in the rhetoric of protecting property rights: just as the law prevents a person from stealing from a company, it could prevent the company from stealing from its workers. What is being stolen is property, which (the Coase analysis recognizes) only exists if the government says it does.

Instead, both "conservatives" and "liberals" accept the classic efficiencyequity trade-off, which says that the market will inevitably be diminished by inefficient meddling by government. Liberals are liberal precisely because they often argue that the trade-off of efficiency for equity is worth it, whereas conservatives typically consider efficiency to be the primary (or only) goal. "Unless the market/non-market dichotomy itself is undone, choosing to value the state over the market-social goals over economic goals-means choosing tails instead of heads in a game of 'heads I win, tails you lose.' "29

\section{The Math Paradox}

A particular source of logical difficulty in mainstream economics relates, oddly enough, to the well-known trend among modern economists to express all arguments in mathematical form. It is certainly plausible to imagine that this de facto requirement will act as a filter to force everyone to make their assumptions known, to confront logical inconsistencies more readily than might be possible when arguments are in verbal form, and to allow for easy comparison of the results of one study with those of another.

To some degree, of course, this happens. The use of mathematical symbols often reminds us to specify whether we are talking about, for example, static values versus rates of growth (for example, price levels versus inflation rates). Unfortunately, the broader hope that mathematical expression would lead to greater clarity has been dashed, as the use of increasingly specialized mathematical techniques seems to have become the raison d'être of much published research (and virtually all graduate training).

Most disturbingly, the proliferation of mathematics in economics has coincided with (and has arguably been a significant cause of) the intellectual crisis of modern economics. The time spent developing and honing the mathematical techniques to make one's points distracts economists from the more important discussions. What will workers and firms do in a world with limited information and conflicting motives, for example? Trying to express arguments in a form that looks scientific paradoxically can make the theory less so. 
THEORIES AND PROOFS

The problem goes deeper, however, than simply the preferred method of expression. Fundamental beliefs in economics have become effectively nonfalsifiable, even though the models used to support those beliefs are regularly overturned. The ultimate game in economic theory has become playing with the assumptions of a model in order to reverse its results. For example, if one paper has "proven" (through the rigorous application of mathematical techniques to a set of assumptions) that affirmative action lowers average economic growth, it is great sport to take that model and reverse its results by changing one seemingly innocuous assumption. The new model, proving that affirmative action increases growth, will then face the same fate.

McCloskey argues forcefully that working through the logic of alternative assumptions in this manner is inherently unscientific. ${ }^{30}$ She refers to this as "blackboard economics," performed by economists to convince themselves that they belong in the mathematics department and not the social sciences division.

Parodying this style, she offers a "Metatheorem on Theorems: The APrime, C-Prime Theorem": "For each and every set of assumptions A implying a conclusion $\mathrm{C}$, and for each alternative conclusion $\mathrm{C}^{\prime}$ arbitrarily far from $\mathrm{C}$-(for example, disjoint with $\mathrm{C}$ ), there exists an alternative set of assumptions $\mathrm{A}^{\prime}$ arbitrarily close to the original assumption $\mathrm{A}$, such that $\mathrm{A}^{\prime}$ implies $C^{\prime}$." Or, to put it more simply: it is possible to change the conclusions as much as one needs by changing the assumptions as little as one likes. That is not science, no matter how much math one uses.

There is abundant evidence that neoclassical economists can and will respond to any "proof" of market inefficiency by inventing yet another reason why markets really are efficient. As a skeptical feminist economist once quipped: "Neoclassical economics is relentless." The answer to every situation is to eliminate deadweight loss by allowing markets to clear. In short, the government should do nothing-and if it is already doing something, it should stop.

An exchange in a recent issue of the Stanford Law Review provides a telling example of the struggle for the mantle of science. The exchange essentially replicates the arguments between neoclassical traditionalists and those who would make adjustments around the edges of that approach, such as information economists.

Jolls, Sunstein, and Thaler argue in favor of an approach to Law and Economics now known as Behavioral Law and Economics. ${ }^{31}$ They take issue with various assumptions favored by the proponents of the traditional Law and Economics approach, especially the rationality assumption. In doing so, they "prove" that under their arguably better assumptions, the results derived by their opponents are reversed. 
In the same issue of the journal, Posner responds to this attack, claiming (among other things) that the rationality assumption is not central to his preferred Law and Economics analysis. ${ }^{32}$ He then claims that the Jolls et al. approach is nonscientific, whereas his approach is the very standard of good science. In a rebuttal, Jolls et al. then claim that, yes, they really are scientific. ${ }^{33}$

In a dissent consistent with that offered here, Kelman chastises both sides, arguing that they "are bound together in a form of rhetorical duet or ritualized dance." 34 This is exactly right. Both sides of the argument are claiming to be scientific, and at least one side is accusing the other of being unscientific, when in fact both sides are simply arguing their beliefs in a way that they think will be forceful. One must certainly decide which side makes a more compelling argument, but not by trying to decide who are the "true" scientists.

\section{STATISTICS AND SIGNIFICANCE}

Because science, according to the standard description, possesses the great virtue of falsifiability, the answer to the blackboard economics problem would seem to lie in the use of advanced statistics and econometrics, which test theories against data. Again, however, the promise is not matched by reality. The two most severe problems spring from what is known as specification searching and a desire to report only "statistically significant" results.

As described again by McCloskey, modern econometrics is involved in its own kind of wasteful game. ${ }^{35}$ Statistical significance, far from demonstrating a "true" cause-and-effect relationship between two variables, is entirely a function of sample size. Find a large-enough data set and it is always possible to compute a statistically significant result. For example, if one is testing whether a key parameter is equal to zero (which is the typical null hypothesis), it is always possible to prove that it is not, given a large-enough sample. After all, even $0.000 \mathrm{I}$ is not zero. ${ }^{36}$

Such an approach is ultimately unsatisfying in both a scientific and a practical sense. The goal should be to find suggestive evidence that something important is happening, not that a parameter differs from zero at a certain level of statistical confidence. To make matters worse, the desire to report statistically significant estimates leads researchers to look for and report only the statistical tests that do just that. ${ }^{37}$ The truth of the underlying theories is not definitively tested by these exercises, nor can it be.

Even more fundamentally important is Leamer's demonstration that the validity of all econometric tests is profoundly sensitive to the choices made by the investigator. ${ }^{38}$ Error in econometric estimation derives from two sources: insufficient sample size and misspecification of the relationship between the variables. ${ }^{39}$ These specification problems arise from choosing which "explanatory" variables to include and exclude, the functional form (linear, log-linear, 
polynomial, etc.), the number and distribution of lags for each variable, and on and on. Leamer shows that in general the misspecification error is of unknown size and sign. Therefore, even if one has solved the sample size problem, the true sign of a statistically significant parameter (which tells us whether an increase in variable $x$ causes variable $y$ to go up or down) literally cannot be known.

Because the uncertainty about the form of the model cannot be reduced by increasing the sample size, misspecification uncertainty always remains, even if sampling uncertainty has been substantially reduced by the fortuitous availability of a large data set. ${ }^{40}$ Even with an enormous data set, estimates that are highly statistically significant can be simply wrong. Therefore, finding that a correlation between variables is statistically significant-or not—cannot be the end of the story. Only careful analysis of all of the available data, studied from a variety of perspectives, can lead to scientific insight. Statistical significance is not a substitute for reasoned judgment.

Leamer's point, therefore, is not that econometrics is a waste of time. Rather, he shows that the moral predisposition of the econometrician can determine the results of the statistical analysis. He gives as an example the question of whether the death penalty is a deterrent to murder. Using different sets of moral principles to guide his choices of specification, he reports (using real data) the range of possible effects on the murder rate from the imposition of capital punishment.

Those whose moral codes make them most likely to advocate the death penalty might specify the equation in a number of ways. Among these possibilities, Leamer's results show that the range of estimated "lives saved per execution" lies roughly between one and twenty-three. On the other hand, a different analyst using different assumptions can find estimates showing that each execution causes as many as twelve more murders, again within a wide numerical range. Leamer also points out that he limited his specifications to linear equations and that he consciously ignored the question of direction of causality.

This is not simply a proof of the old adages "There are lies, damned lies, and statistics" and "Figures lie, and liars figure." The implication is much larger. Anyone undertaking statistical analysis brings to the table their own morals and opinions. It cannot be otherwise. Statistics and econometrics are not, and cannot be, value neutral.

Hence, the paradox: the more mathematics we use, the less scientific we might become. The great irony is that those who would apply to their own fields of analysis the methods championed by neoclassical economistsspecifically to avoid the accusation of being soft or mushy-headed-are imposing on themselves and their colleagues the necessity of learning an obscure set of skills that does not guarantee scientific purity. 


\section{Neoclassical Economics Is Morally Troubling}

For many readers who have reached this point, the rest of the story may seem obvious. Neoclassical economics has been used to justify everything from pollution to discrimination against women to "efficient" suicide. What more needs to be said about its morally troubling nature? Actually, there are two paths to take in describing the moral difficulties of neoclassical economics. The first directly confronts the neoclassical theory of value to expose the moral implications of believing that everything can be bought and sold. The second indirectly exposes neoclassical immorality by showing that the model is inherently wedded to a defense of the status quo.

\section{The More Obviously Troubling Moral Implications}

The willingness-to-pay criterion defines everything as having a value measurable in dollars. Everything has a price, including the unthinkable. One former student, who was truly enamored of this theory of value (and who is now a professor at the Harvard Business School), insisted on asking all of his friends in college how much they would have to be paid to drive a nail through a live squirrel's head. People who said that they simply would not do so were quickly offered exorbitant sums and told that they could use the money to help the poor, or squirrels, or whatever.

Lest one think that this was merely the excesses of youth, a middle-aged neoclassical economist remarked to a group of colleagues that he could not understand why a house he had just walked past had a "for sale" sign on the lawn. After all, he noted, everything is for sale. A listener muttered under his breath: "How much for your daughter?"

The point is that we should not feel guilty about creating deadweight losses, because they merely represent unconsummated trades. There are, of course, many transactions that people might make in the hypothesized neoclassical state of nature that are prohibited in modern societies, such as selling one's child into slavery. Indeed, by the lights of the most pure form of neoclassical theory, why not let people make the choice to sell their children or to become slaves themselves, since we can easily define those property rights and enforce them? It is a sad commentary that this question, for many neoclassicists, is not rhetorical.

The power of the neoclassical model to excuse and rationalize the status quo is also well established. Poverty is nothing to worry about-or at least nothing to do something about. Unequal distributions of income are easily justified by neoclassical theory as "returns" to different talents and attributes. If it is not obvious just what the talent or attribute is that made a person rich, one need only look a bit harder for it. Perhaps it is entrepreneurship, which is wonderfully impossible to define. Whatever it is, though, it simply must be there or a rational maximizer would not have paid for it. 
Similarly, discrimination cannot exist in a free market, except when the discriminators are willing to pay the price for the privilege of discriminating. ${ }^{41}$ If we have difficulty discerning the rationality of people's decisions (for example, discrimination that is apparently costly to the discriminators), the problem again is that we are not looking hard enough. The market guarantees that only efficient decisions will be made.

In a recent article in the popular press, Barro makes this point quite bluntly. ${ }^{42}$ (Barro, a macroeconomist at Harvard, is one of the founders of a fundamentalist strain of neoclassicism called New Classical Economics.) Arguing against laws that prevent employers from using physical appearance as a standard in hiring and promotion, Barro simply assumes that anything that employers do is guided by profit motivation and must, therefore, lead to Pareto efficiency.

An interference with the market's valuation of physical appearance is justified only if the benefits from the redistribution of resources from more attractive to less attractive people are greater than the losses in overall product. Thus, it makes no sense to say that basing employment and wages on physical appearance is a form of discrimination, whereas basing them on intelligence is not. The two cases are fundamentally the same.

If one removes the words physical appearance and attractive and replaces them with race and white, Barro's statement is so outrageous as to be politically incendiary.

An interference with the market's valuation of race is justified only if the benefits from the redistribution of resources from more white to less white people are greater than the losses in overall product. Thus, it makes no sense to say that basing employment and wages on race is a form of discrimination, whereas basing them on intelligence is not. The two cases are fundamentally the same.

Of course, very few neoclassicists would make that statement about race (in public, anyway), because the current morals of society strongly endorse the notion that racial equality is a basic right. This is precisely as it should be. Certain rights are inalienable. Therefore, they are not the same as preferences, to be bargained away for a price. Our approach to issues of human equality should be the model for our approach to all public policy issues: specify our values first, and pursue the best route to affirming those values.

COMPENSATION - REAL AND HYPOTHETICAL

Even for those who are willing to join Dr. Pangloss in believing that the world is already perfect, there are still many pitfalls of neoclassical reasoning. When 
faced with a deadweight loss, for example, there are two established methods of dealing with it. One is simply to remove the impediment to Pareto efficiency, such as eliminating the minimum wage. However, how can it be the case that this is a way to "make some better off without making others worse off," when clearly some workers will be hurt by a decline in their wages? The answer is the "compensation criterion," which notes that the elimination of deadweight loss always implies that the gains are larger than the losses, so that it would be possible for the winners to compensate the losers and still have money left over. If the compensation is not actually made, however, then this is obviously just a logic game to justify taking from some people and giving to others. ${ }^{43}$

Moreover, it is daunting in the extreme to imagine how to implement a plan in which, for example, those who gain from eliminating a rent control law actually pay off those who lose. Because gains and losses are often entirely psychological (and are measured by the willingness to pay), it is not possible to elicit honest answers to the question "How much have you gained or lost due to this change?"

As Crawford discusses, the point of the compensation criterion was to separate efficiency from distribution. ${ }^{44}$ Arrow pointed out, however, that this separation is simply not possible. ${ }^{45}$ Claiming to be more efficient requires a standard of measurement that depends on the distribution of endowments, as noted in a discussion earlier in the chapter. ${ }^{46}$

The second, and more limited, response to the discovery of deadweight loss is to enact a policy only if one can be found that does not require compensation to losers. As one workshop participant put it: "Why not make everyone better off, if you can do it without making anyone else worse off?"

Claiming to have found a policy that makes everyone better off without making anyone worse off, though, requires a definition of the terms better off and worse off. If one uses the willingness-to-pay criterion, the result is to accept the moral primacy of this theory of value. At the very least, those who propose such policies should be forced to admit that this is their moral standard.

More profoundly, once we agree that an appropriate goal of policy is to eliminate deadweight losses, we lose a clear reason to oppose uncompensated losses. After all, if we are willing to believe that deadweight loss is bad enough to go to the trouble of enacting a policy that hurts no one, what is so wrong with eliminating deadweight loss by only hurting a few people? (Especially if those people are politically powerless?) How many is too many to hurt? By how much can they be hurt before we start to worry?

The neoclassical theory of value leads to results that are morally troubling for those of us who are concerned with poverty, discrimination, and that elusive concept called justice. Agreeing to measure social outcomes by the neoclassical standard might well lead us to endorse policies that we would-and should-otherwise reject. 


\section{Some Subtle Moral Issues}

In a famous attack on the immorality of neoclassicism and Pareto efficiency, Sen argued: "An economy can be optimal in this sense even when some people are rolling in luxury and others are near starvation as long as the starvers cannot be made better off without cutting into the pleasures of the rich. ... In short, a society or an economy can be Pareto-optimal and still be perfectly disgusting." 47

The neoclassical response to Sen's argument is that there is more than one situation that is Pareto-efficient. As noted earlier, the initial endowments of the actors in an economy determine a unique general equilibrium. One can construct any original set of endowments, and a general equilibrium model will generate the Pareto-efficient market prices and quantities. Therefore, one might argue, there is no morality or immorality behind Pareto efficiency because any situation can be the Pareto-efficient general equilibrium from some hypothetical initial set of endowments.

This is true but unsatisfying. Imagine that we were willing to measure value by the neoclassical standard but that we insisted on redistributing endowments in a way that would make the Pareto-efficient general equilibrium results morally tolerable. This method could rightly be attacked as Pareto-inefficient because taking endowments away from one person and giving them to another is a nonmarket act. In other words, taking away endowments from one party is Pareto-inefficient by the current standard, even while its very purpose is to create a different Pareto-efficient general equilibrium.

This contradiction puts into sharp focus the ultimate import of neoclassical economics: Any attempt to alter the status quo is inefficient by the standard of the current endowments. These endowments are privileged in the analysis simply because they exist.

CHASING OUR TAILS

Anyone who tries to choose the policies that will minimize deadweight losses will encounter this problem in a different form. For example, those who advocate minimum wages will learn from a standard textbook that deadweight losses are smaller if we simply subsidize incomes rather than "interfering" in the employment relationship. Similarly, any use of legal rules (such as antitrust enforcement) to redistribute income is ill-advised because the legal system should promote efficiency, "leaving distribution to the tax system." 48

Subsidies themselves are Pareto-inefficient, however, because they too involve government interference in the marketplace. Using taxes-whether to pay for the subsidies or as redistributive tools in their own right-is also, of course, doomed by the same reasoning. Should we, nevertheless, choose the type of tax that creates the least deadweight loss? In a return of the blackboard 
economics problem discussed above, some tax analysts argue that estate taxes create less deadweight loss than any other type of tax, whereas others purport to prove that estate taxes are the most offensive taxes of all. ${ }^{49}$

We are pushed, therefore, from one policy to the next, with each move justified by its lesser amount of deadweight loss. Ultimately, by that logic, the only acceptable policy is to do nothing at all-or simply to choose to live with an arbitrary level of deadweight loss. Because the promise of adopting a scientific method was that it would be nonarbitrary, however, what have we gained?

The logic underlying neoclassical economics is particularly well suited to justifying the current distribution of wealth and power. To adopt neoclassical analysis is to risk predetermining our conclusions.

\section{Old Vinegar in New Bottles}

As noted earlier, many pure economic theorists have moved past the neoclassical general equilibrium approach. Some argue that the entire concept of markets and social welfare should be dropped, preferring game theory to analyze behavior of all types. Both the virtue and the pitfall of this argument are that game theory, in its purest form, makes no claims to any type of morality. One can specify any set of assumptions about how people react to stimuli, define the rules of the game, and predict a result. The result is neither good nor bad. It just is.

If such an amoral alternative exists, economists who continue to use the value-laden prescriptions of neoclassical economics apparently do not find those prescriptions sufficiently troubling to look for an alternative. However, the moral bases of neoclassical economics can operate more subtly as well. Some (if not most) game theory seems to be little more than repackaged neoclassicism. Most importantly, efficiency in game theory models is still typically measured by the standard of Pareto efficiency.

Claiming to present a "rigorous" analysis of the marriage market, for example, Wax simply imported a sexist assumption into a rational choice model-that women want to marry men more than men want to marry women. ${ }^{50}$ The model then proved that women have a harder time in the marriage market-because men are less inclined to marry than are women! This circular result is simply the "equilibrium" that results from the assumed gender-based differences in preferences.

Changing the analytical tools does not change the implications of neoclassical assumptions, nor does it obviate the logical certainty that the typical neoclassical conclusions will be reached. The important thing is not merely to avoid concerning ourselves with deadweight losses but to make sure that the assumptions and-more to the point-the standards of judgment that we use are not rigged against us. 
There is no good reason for noneconomists (or for non-neoclassical economists) to believe that the neoclassical approach is logically or scientifically compelling. Also, because the moral precepts of the approach are troubling, it is both unwarranted and self-defeating for feminist legal theorists and other progressive scholars to adopt its methods.

\section{Concluding Thoughts}

The arguments in this essay add up to the claim that it is dangerous to adapt neoclassical economic methods to feminist legal analysis-and, more generally, to all progressive social research agendas. The result of such adaptation is an unacceptable mutation -if not an outright repudiation-of the underlying concept of justice that motivates most feminist analysis, a concept that at least contemplates the possibility of fundamental social change. This is why the argument that we have to use neoclassical methods in order to be listened to is ultimately unpersuasive. Even if such an assertion were true, there would be precious little point in being listened to if we have nothing meaningful to say.

The danger, however, is not merely that using neoclassical methods will damage legal analysis piecemeal in those situations in which we try to apply it. The potential danger is much more sweeping: if we adopt some neoclassical methods, we are likely eventually to find ourselves adopting the entire neoclassical approach (both methods and values). This is a warning, not a prediction. However, we actually have plenty of evidence that this not only might happen but that it almost certainly will happen if we start down that road. Neoclassical economics acts as an imperialist force, imposing its methods and its presumptions on every field that it touches. ${ }^{51}$

For example, thirty-five years ago, some macroeconomists argued that their analysis would be improved by explicitly describing the behavioral assumptions underlying their models. Today, the leading journals in the field almost exclusively publish papers whose models are based on general equilibrium frameworks, on the basis of the assumption that all actors have rational expectations.

Similarly, tax analysis in the mainstream of the profession is almost completely dominated by the neoclassical approach. Finance was routed long ago. A sizable group of labor economists continues to resist an intense assault. As for the disciplines outside of economics that have flirted with neoclassicism (evolutionary biology, sociology, history, political science, as well as several areas of legal analysis), either they have lost the battles to maintain some of their non-neoclassical methods or they have found the fight to be long and protracted.

Feminist legal analysis, like all fields of social analysis, should certainly use whatever sound analytical principles are available. Far from being an argument 
in favor of adopting neoclassical principles, however, this statement is actually an emphatic reason to reject mainstream economics. The law should continue to be about justice and morality. It is essential that we consciously choose our moral principles rather than having them surreptitiously thrust upon us.

\section{Notes}

I. I thank Benjamin L. Alpers, Michael C. Dorf, Terence Dougherty, Lucinda M. Finley, Nicole C. Palasz, and an anonymous referee for their helpful comments. Douglas A. Kysar's comment following this chapter is extremely insightful and suggests many promising directions for future research. I also acknowledge the helpful input of the participants in the Feminism and Legal Theory workshops at Columbia and Cornell Law Schools and the participants in a panel at the I 999 Law and Society meetings. Finally, I owe a debt of gratitude to Martha A. Fineman, who not only supported and encouraged this project but also convinced me that I was not too old to go to law school.

2. Rigorous is one of the favorite words of proponents of neoclassical economics. Another is scientific. Some of the undesirable adjectives are soft, squishy, anecdotal, and sociologicai.

3. There are, of course, legal theorists whose personal morals would not be offended by the political agenda that neoclassical economics supports. While it is unlikely that many of them would identify themselves as feminists, even they would be wise to lay out their principles explicitly, rather than importing them wholesale from a paradigm that includes many hidden (potentially less appealing) assumptions. Therefore, while some of the discussion that follows will resonate most readily with political progressives, the message applies to everyone who might consider using neoclassical economics to analyze social issues.

4. Lochner v. New York, I98 U.S. 45 (1905).

5. Another common description of Pareto efficiency is the following: "A situation is Paretoefficient when it is not possible to make someone better off without making someone else worse off." This description is discussed in detail later in the chapter.

6. Overproduction is not analyzed as frequently as is underproduction. For the remainder of this discussion, for the sake of clarity, only the implications of underproduction are described.

7. Robert Cooter \& Thomas Ulen, Law and Economics 40 (3d ed., Addison-Wesley 2000).

8. Peng Lian \& Charles Plott, General Equilibrium, Markets, Macroeconomics, and Money in a Laboratory Experiment Environment, I 2 Econ. Theory I (1998). Alex Anas \& Rong Xu, Congestion, Land Use, and Job Dispersion: A General Equilibrium Model, J. Urban Econ. (1999).

9. Douglas W. Elmendorf \& N. Gregory Mankiw, Government Debt 32, Finance and Economics Discussion Series 1998-99 (Federal Reserve Board 1998).

Iо. Among countless examples, see Georg Hirte \& Reinhard Weber, Pareto Improving Transition from a Pay-as-You-Go to a Fully Funded System-Is It Politically Feasible? 54 FinanzArchiv 3 (1997).

I I. Actually, this is somewhat misleading. The official Nobel web site distinguishes very clearly between the actual Nobel Prizes and the economics prize: "Announcement for the 1998 Nobel Prizes and the Sveriges Riksbank (Bank of Sweden) Prize in Economic Sciences in Memory of Alfred Nobel."

I2. "To be sure, macroeconomics is a young and imperfect science." N. Gregory Mankiw, Macroeconomics 3 (4th ed. 2000).

I3. For a demonstration and discussion of false trading, see Neil H. Buchanan, A Simple Demonstration of False Trading and Its Implications for Market Equilibrium (unpublished) (available on request from the author).

I4. Franklin M. Fisher, Adjustment Processes and Stability, in The New Palgrave: A Dictionary of Modern Economics, vol. I, at 26 (John Eatwell, Murray Milgate, \& Peter Newman eds., Macmillan 1987). 
1 5. Id. at 27 (emphasis added).

16. This is a general equilibrium version of the Theory of Second Best, first described in a partial equilibrium context in R. G. Lipsey \& Kelvin Lancaster, The General Theory of Second Best, 24 Rev. Econ. Stud. I, I I-32 (1956-57). See also Richard S. Markovits, Symposium on SecondBest Theory and Law and Economics: An Introduction, 73 Chi.-Kent L. Rev. 3 (1998), and the symposium introduced thereby.

I7. This belief must be at the root of attempts to expand the reach of neoclassical economic analysis into areas that were previously untouched by such thinking. Judge Posner's insistence on applying economic analysis to sex-although a spectacular failure-is certainly the most infamous such attempt. See Richard A. Posner, Sex and Reason (Harvard U. Press I992).

I 8. For a good critique of this concept, see Lawrence Summers, The Scientific Illusion in Empirical Macroeconomics, 95 Scan. J. Econ. 2, I 29-48 (1991).

19. This is distinct from the earlier discussion about changes in endowments. Even under a given set of endowments, curves can shift because of changes in tastes and technology.

20. See John Eatwell \& Murray Milgate, Introduction, in Keynes's Economics and the Theories of Value and Distribution (John Eatwell \& Murray Milgate eds., Oxford U. Press 1983) (exposing the fallacy of this notion of equilibrium).

21. Patrick B. Crawford, The Utility of the Efficiency/Equity Dichotomy in Tax Policy Analysis, 16 Va. Tax Rev. 517 (1997).

22. George Akerlof, The Market for Lemons: Quality Uncertainty and the Market Mechanism, 84 Q.J. Econ. 488 (1970).

23. Joseph E. Stiglitz, Post Walrasian and Post Marxian Economics, 7 J. Econ. Persp. Io9 (1993).

24. There are at least four different efficiency wage models. The model described here is known as the adverse selection model.

25. See Lorne Carmichael, Can Unemployment Be Involuntary?: Comment, 75 Am. Econ. Rev. I 2 I3-I4 (1985).

26. See Carl A. Shapiro \& Joseph E. Stiglitz, Can Unemployment Be Involuntary?: Reply, 75 Am. Econ. Rev. I 1 15-17 (1985).

27. See Hal R. Varian, Intermediate Microeconomics: A Modern Approach, 562-63 (4th ed., Norton 1996).

28. See Martha McCluskey, Telling Stories about the State and the Market: The Rhetorical Construction of Efficiency, presented at Feminism and Legal Theory Workshop: Feminism Confronts Legal Theory, Columbia Law School (February 1995).

29. See McCluskey, chapter 8 , this volume.

30. See Deirdre.N. McCloskey, Two Vices: Proof and Significance, presented at the annual meetings of the American Economic Association, Chicago, Ill. (Jan. 3, I998); Deirdre N. McCloskey, The Vices of Economists and the Virtues of the Bourgeoisie (U. of Michigan Press 1998).

3 I. Christine Jolls, Cass R. Sunstein, \& Richard Thaler, A Behavioral Approach to Law and Economics, 50 Stan. L. Rev. I47I (1998).

32. Richard A. Posner, Rational Choice, Behavioral Economics, and the Law, 50 Stan. L. Rev. I 55 I (1998).

33. Christine Jolls, Cass R. Sunstein, \& Richard Thaler, Theories and Tropes: A Reply to Posner and Kelman, 50 Stan. L. Rev. I 593 (1998).

34. Mark Kelman, Behavioral Economics as Part of a Rhetorical Duet: A Response to Jolls, Sunstein, and Thaler, 50 Stan. L. Rev. 1577 (1998).

35. See supra note 30.

36. See Deirdre N. McCloskey \& Stephen Ziliak, The Standard Error of Regressions, 34 J. Econ. Lit. I, 97-I I4 (I996).

37. See J. Bradford De Long \& Kevin Lang, Are All Economic Hypotheses False? roo J. Pol. Econ. I257-72 (1992).

38. Edward E. Leamer, Let's Take the Con out of Econometrics, 73 Am. Econ. Rev. I, 3 I-43 (1983). 
39. Id. at 32 .

40. Id.

4 I. Probably the most frank statement of this is in Milton Friedman, Capitalism and Freedom (U. of Chicago Press 1962).

42. Robert Barro, So You Want to Hire the Beautiful. Well, Why Not? Business Week I 8 (Mar. 16, 1998).

43. Those readers who are familiar with Kaldor-Hicks efficiency will notice that it too relies (n) the set of general equilibrium outputs as its reference point. Its only difference is in allowing policy actions to be enacted without compensation, so long as the losers could have been compensated as we move from a less Pareto-efficient set of outputs toward a more Pareto-efficient set.

44. See Crawford, supra note $2 \mathrm{I}$, at $5 \mathrm{I} 7$.

45. Kenneth J. Arrow, Social Choice and Individual Values (2d ed., Yale U. Press 1970).

46. In addition, in his summary of the findings of information economics, Stiglitz goes on to say that "[ $t]$ he distribution of income does matter. The neat dichotomy between efficiency and distribution is not, in general, valid." Stiglitz, supra note 23, at I09.

47. Amartya Sen, Collective Choice and Social Welfare (Holden-Day 1970).

48. Philip Areeda \& Louis Kaplow, Antitrust Analysis: Problems, Text, Cases 25 ( 5 th ed., Aspen 1997), citing L. Kaplow \& S. Shavell, Why the Legal System Is Less Efficient Than the In(o)me Tax in Redistributing Income, 23 J. Legal Stud. 667 (1994).

49. See Joseph A. Pechman, The Rich, the Poor, and the Taxes They Pay (Westview 1986); and Bill Beach, The Case for Repealing the Estate Tax (Heritage Found. 1996).

50. Amy Wax, Is There a Future for Egalitarian Marriage? presented at Feminism and Legal Theory Workshop: Economic Discourse and the Family, Columbia Law School (March I998).

$5 \mathrm{I}$. For an unapologetic endorsement of the spread of neoclassical economics into other fields, see Edward P. Lazear, Economic Imperialism, I 5 Q.J. Econ. 99 (2000). Among many highly quotable claims, Lazear states approvingly that "economics has been imperialistic and . . . economic imperialism has been successful." Id. at ro3. 